\title{
Characteristics of uterine leiomyoma patients at the Department of Obstetrics and Gynecology, Dr. Soetomo Hospital, Surabaya, from January to December 20 I 4
}

\author{
Listiana Rizka Pranandari', Hari Nugroho², Dwi Aprilawati ${ }^{3}$ \\ 'Medical Doctor Program, ${ }^{2}$ Department of Obstetrics and Gynecology, ${ }^{3}$ Department of Public Health \\ and Preventive Medicine, Faculty of Medicine, Universitas Airlangga, Surabaya
}

\begin{abstract}
ABSTRAK
Tujuan: Untuk mempelajari karakteristik penderita leiomyoma uteri untuk digunakan sebagai bahan acuan serta bahan evaluasi. Bahan dan Metode: Studi dilakukan dengan mempelajari rekam medis penderita kemudian menilai gambaran umum penderita.

Hasil: Dari 145 penderita, mayoritas adalah perempuan berusia $>40$ tahun $(69.7 \%)$. Penderita masih haid memiliki presentase yang tinggi terjadi leiomyoma uteri (31\%). Empat penderita $(2.8 \%)$ menggunakan kontrasepsi oral dan lebih banyak penderita dengan riwayat menarche antara 12-13 tahun (15.2\%). Leiomyoma uteri juga lebih banyak pada penderita dengan riwayat kehamilan $<2$ kali $(35.2 \%)$ dan sama halnya dengan riwayat kelahiran $(37.2 \%)$. Mayoritas penderita leiomyoma uteri tidak pernah merokok $(63.4 \%)$ dan BMI overweight $(29,7 \%)$. Tidak terdapat data pada seluruh rekam medis mengenai riwayat keluarga, kebiasaan olah raga dan riwayat cidera uterus.

Simpulan: Mayoritas penderita leiomyoma uteri adalah perempuan pada usia lebih dari 40 tahun dan masih haid atau perimenopause dengan riwayat kehamilan dan kelahiran kurang dari atau sama dengan 2 kali, tidak pernah mengonsumsi rokok dan berat badan lebih dari normal. (MOG 2017;25:81-85)
\end{abstract}

Kata kunci: leiomyoma uteri; tumor jinak rahim; epidemiologi; karakteristik penderita; Surabaya; Indonesia

\begin{abstract}
Objectives: To study the characteristics of patient with uterine leiomyoma to be used as reference and evaluation.

Materials and Methods: The data of this study taken by assessing patients' medical record to be analyzed descriptively.

Results: Of 145 patients, 69,7\% were female who are older than forty years of age. Uterine leiomyoma often occur in patients of reproductive age $(31 \%)$. Only $2.8 \%$ patient used oral contraceptive and $15.2 \%$ had menarche at the age of $12-13$ years. The number of uterine leiomyoma was higher in female who had history of pregnancy less than or equal to two times $(35.2 \%)$ and dominated by patients who had history of birth less than or equal to two times $(37.2 \%)$. $63.4 \%$ patient never consume cigarette. Moreover, $29.7 \%$ of patients were overweight female. Unfortunately, there is no data about family history, exercise habit and history of tissue injury in the medical record.

Conclusion: In this study, patients with uterine leiomyoma are dominantly female at age more than forty and at reproductive or perimenopause period with history of pregnancy and birth less than or equal to 2 times, never consume cigarette and overweight. (MOG 2017;25:81-85)
\end{abstract}

Key words: uterine leiomyoma; benign neoplasm in uterus; epidemiology; characteristics of patient; Surabaya; Indonesia

Correspondence: Listiana Rizka Pranandari. Medical Doctor Program, Faculty of Medicine, Universitas Airlangga, Jalan Prof. dr. Moestopo 47, Surabaya 60131, East Java, Indonesia. Phone: +6287854844646. E-mail: listianarizka@ gmail.com

\section{INTRODUCTION}

Uterine leiomyoma or fibroid or myoma is the most common benign neoplasm of the genital organs in women. ${ }^{11}$ Uterine leiomyoma is the most common asymptomatic cases but it can cause abnormal uterine bleeding1. Leiomyoma are the major cause of morbidity in women of a reproductive age and sometimes even after menopause. ${ }^{3}$ The mechanisms involved in the cellular transformation of myometrium cells into leiomyoma remains unknown, ${ }^{4}$ but it might be either leiomyoma or estrogen exposure. Some factors possibly related with the formation of uterine leiomyoma are age, menstrual status, body mass index, family history, early menarche, and African-American. And some factors that inhibit the occurrence of uterine leiomyoma are pregnancy, contraception, smoking and menopause. ${ }^{4}$ Uterine leiomyoma commonly found during reproductive age and their frequency decreases with menopause. ${ }^{3}$ Some study has found a reduced risk of leio- myoma formation was determined in women who take physical exercise. ${ }^{4}$

\section{MATERIALS AND METHODS}

This study was a descriptive-observational study focused on the prevalence of uterine leiomyoma. The data of this study were taken by assessing medical record of uterine leiomyoma patients at the Department of Obstetrics and Gynecology of Dr Soetomo Hospital in Surabaya from January to December 2014. The population sample of this study was all patients diagnosed with uterine leiomyoma at the Department of Obstetric and Gynecology in Dr Soetomo Hospital Surabaya from 1 January to 31 December 2014. The variables observed in this study were patient' age, family history, body mass index, menstrual status, exercise habits, oral contraceptive use, history of birth, history of pregnancy, smoking habit, history of tissue injury and menarche. 
All data collected to be analyzed descriptively by grouping according to variables.

\section{RESULTS AND DISCUSSION}

In this study, we found 145 cases of uterine leiomyoma from January to Desember 2014, but each medical record doesn't have all variables needed. From 11 variables mentioned, the data about family history, exercise habit and history of tissue injury are unavailable in the medical record, so in this research, those data are excluded and not discussed.

Table 1. Age distribution

\begin{tabular}{ccc}
\hline \multicolumn{1}{c}{ Age } & Amount & Percentage (\%) \\
\hline $21-30$ years old & 11 & 7.6 \\
$31-40$ years old & 33 & 22.8 \\
$>40$ years old & 101 & 69.7 \\
\hline
\end{tabular}

Table 2. Body mass index distribution

\begin{tabular}{lcc}
\hline \multicolumn{1}{c}{ BMI $\left(\mathrm{kg} / \mathrm{m}^{2}\right)$} & Amount & $\begin{array}{c}\text { Percentage } \\
(\%)\end{array}$ \\
\hline Underweight $(<18.5 \mathrm{~kg} / \mathrm{m} 2)$ & 4 & 2.8 \\
Normal $(18.50-24.99 \mathrm{~kg} / \mathrm{m} 2)$ & 25 & 17.2 \\
Overweight $(25-29.99 \mathrm{~kg} / \mathrm{m} 2)$ & 31 & 21.4 \\
Obesity $(\geq 30 \mathrm{~kg} / \mathrm{m} 2)$ & 17 & 11.7 \\
No data & 68 & 46.9 \\
\hline
\end{tabular}

Table 3. Menstrual status distribution

\begin{tabular}{lcc}
\hline \multicolumn{1}{c}{ Menstrual status } & Amount & $\begin{array}{c}\text { Percentage } \\
(\%)\end{array}$ \\
\hline Reproductive age & 45 & 31 \\
Menopause & 13 & 9 \\
No data & 101 & 60 \\
\hline
\end{tabular}

Table 4. Oral contraception use distribution

\begin{tabular}{lcc}
\hline Oral contraception use & Amount & Percentage (\%) \\
\hline No consume & 33 & 22.8 \\
Consume & 4 & 2.8 \\
No data & 108 & 74.5 \\
\hline
\end{tabular}

Table 5. History of pregnancy distribution

\begin{tabular}{lcc}
\hline \multicolumn{1}{c}{ History of pregnancy } & Amount & Percentage (\%) \\
\hline Not pregnancy yet & 36 & 24.8 \\
One or two times & 51 & 35.2 \\
More than two times & 32 & 22.1 \\
No data & 26 & 17.9 \\
\hline
\end{tabular}

Table 6. History of birth distribution

\begin{tabular}{lcc}
\hline \multicolumn{1}{c}{ History of birth } & Amount & $\begin{array}{c}\text { Percentage } \\
(\%)\end{array}$ \\
\hline Not birth yet & 43 & 29.7 \\
One or two times & 54 & 37.2 \\
More than two times & 22 & 15.2 \\
No data & 26 & 17.9 \\
\hline
\end{tabular}

Table 7. Smoking habit distribution

\begin{tabular}{lcc}
\hline \multicolumn{1}{c}{ Smoking habit } & Amount & Percentage (\%) \\
\hline No smoke & 92 & 63.4 \\
Less than 5 cigarette a day & 2 & 1.4 \\
$5-10$ cigarette a day & 0 & 0 \\
10 cigarette a day & 1 & 0.7 \\
No data & 50 & 34.5 \\
\hline
\end{tabular}

Table 8. Menarche distribution

\begin{tabular}{lcc}
\hline \multicolumn{1}{c}{ Menarche } & Amount & $\begin{array}{c}\text { Percentage } \\
(\%)\end{array}$ \\
\hline Less than 12 years old & 3 & 2.1 \\
12 - 13 years old & 22 & 15.2 \\
13 years old & 19 & 13.1 \\
No data & 101 & 69.7 \\
\hline
\end{tabular}

Age

During reproductive age, the incidence of uterinne leiomyoma increases exponentially with age 4 . In this research, uterine leiomyoma often occur on women aged forty and older with percentage $69,7 \%$. It showed a similarity with Wise el al' research about the increasing incidence of uterine leiomyoma on 40-44th years old as much as $45,6 \%$ in 2637 women with uterine leiomyoma. ${ }^{5}$ Whether the risk of new fibroids actually increases rapidly in women during their forties is remain unknown. If the likelihood of fibroid development and growth actually accelerates during the late reproductive years, hormonal factors associated with pre-menopause may be important modulators; alternatively, the apparent increase in the late reproductive years may simply represent the cumulative culmination of 20-30 years. ${ }^{6}$

\section{Body Mass Index}

In this research patient who has body mass index between $25-29.99 \mathrm{~kg} / \mathrm{m} 2$ or overweight, most frequently has uterine leiomyoma as much as $21.4 \%$. It is because overweight as a metabolic syndrome is a significant factor related to formation of uterine leiomyomas. ${ }^{7}$ Beside, researches done in 1995-2006 showed that women with obesity $(\geq 30.00 \mathrm{~kg} / \mathrm{m} 2)$ have increased risk of uterine leiomyoma formation (RR 1.33) same 
with overweigh (25.00-29.99 kg/m2, RR 1.26) compared with women who has normal body mass index (18.5$24.9 \mathrm{~kg} / \mathrm{m} 2$, RR 1,00$)^{8}{ }^{8}$

This apparent association between obesity and an increased risk of fibroids possibly related to hormonal factors. A significant increase occurs in the conversion of circulating adrenal androgens to estrone by excess adipose tissue. Otherwise, The hepatic production of sex hormone-binding globulin is decreased, resulting in more unbound physiologically active estrogen. Obese premenopausal women, decreased metabolism of estradiol by the 2- hydroxylation route reduces the conversion of estradiol to inactive metabolites, which could result in a relatively hyperestrogenic state. ${ }^{6}$

\section{Menstrual status}

Patient who still menstruating or reproductive age, have big percentage due to uterine leiomyoma in this research as much as $31 \%$. That result are identical with the study that showed uterine leiomyoma rarely appear before menarche and regress after menopause. ${ }^{9}$ Otherwise, leiomyoma are diagnosed in $20-25 \%$ of women of reproductive age, and $30-40 \%$ of women at premenopausal period. ${ }^{10}$

Myomas are smaller and less numerous in hysterectomy specimens from postmenopausal women. Uterine leiomyoma that need surgery decreased in post-menopausal patient, it is possibly caused by the shrinkage of uterine leiomyoma due to no hormonal stimulation after menopause. $^{11}$

\section{Oral contraception}

Prior studies have not provided consistent results regarding risks with oral contraceptive (OC) use due to uterine leiomyoma formation. There was no association between past or current oral contraceptive use, or age at first oral contraceptive use to uterine leiomyoma. Although those with very short-term oral contraceptive use $(<1$ year) had greater risk than women who had used oral contraceptives for 1 to 4 years. ${ }^{8}$

A study shows decrease risk of uterine leiomyoma occur in current users of progestin-only injectable, This is possibly occurred due to the down regulation of the estrogen receptors in leiomyoma caused by progestin 10 . Beside, risk of Uterine Leiomyoma morbidity was reduced by $17 \%$ in "ever" use oral contraception for 5 consecutive years or more, but there was significant heterogeneity. ${ }^{12}$

In this research, $2.8 \%$ patient use oral contraception while $22.8 \%$ patient not consumes oral contraception.
This may happen because medical record majority lacking data about oral contraception use.

\section{History of pregnancy}

This research shows uterine leiomyoma often in patient with history of pregnancy one or two times as much as $35.2 \%$. Increased history of pregnancy can decrease prevalence of uterine leiomyoma because pregnancy is a condition where progesterone are more dominant than estrogen, so there is a space to estrogen exposure an it can inhibit uterine leiomyoma formation. ${ }^{4}$

Patient who never had pregnancy also has high pregnancy as much $24.8 \%$. There is relation uterine leiomyoma can make infertility even rare13. Infertility may occur when uterine leiomyoma is big, submucosa, soliter, or there is uterine distortion. Uterine leiomyoma can change uterine contractility so it can disturb sperm migration. Patient who had submucosa uterine leiomyoma has $70 \%$ probability to pregnant 1 year after surgery. ${ }^{4}$

\section{History of birth}

This research show that patient with history of birth one or two times has highest percentage $37.2 \%$ compared to not birth yet and more than two times. This may because history of birth and pregnancy happen when patient less than 25th years old when no formation uterine leiomyoma or 25-29th years old also known as midproductive age as biggest protection of uterine leiomyoma. $^{14}$

Previous studies have reported an inverse relationship between uterine leiomyoma parity8. That because uterine remodeling during postpartum4. There have been some suggestions that during postpartum uterine remodeling, there could be selective apoptosis of small lesions and ischemia during parturition has also been proposed as a mechanism. ${ }^{2}$ Otherwise uterine leiomyoma is known to increase the risk of spontaneous abortion at first trisemester. ${ }^{14}$

\section{Smoking habit}

This research shows uterine leiomyoma often found on women who has no smoking habit. It based on theory known that smoking can decrease the risk of leiomyoma. ${ }^{5}$ Many study showed decreasing risk of uterine leiomyoma associated with smoking habit is around 76.3\% . Consistently smoking is a risk factor in decreasing number of uterine leiomyoma around 20$50 \%{ }^{14}$

The inverse correlation between smoking and uterine leiomyoma has been commonly attributed to an anti- 
estrogenic effect of cigarette smoking, suggested by other epidemiologic associations of smoking, including a reduced risk of endometrial cancer, earlier natural menopause, and increased osteoporosis. ${ }^{6}$ Decrease incidence of uterine leiomyoma cause by cigarette is often linked by significant relation between decrease Body Mass Index and smoke. ${ }^{14}$ Otherwise several derangements of steroid metabolism have been identified in smokers, increased 2-hydroxylation of estradiol resulting in decreased bioavailability at estrogen target tissues, nicotine inhibition of aromatase reduces the conversion of androgens to estrone, Significantly higher serum levels of sex hormone-binding globulin have been found, resulting in less unbound physiologically active estrogen. ${ }^{6}$

\section{Menarche}

Each women has different menarche, the average age is 13th years old in Indonesian. ${ }^{15}$ While the average age of menarche in worldwide is between 12-13th years old, on good nutrition population. ${ }^{16}$ Early menarche or less than 10th years old increase risk of uterine leiomyoma compared patient who had menarche at $13{ }^{8}$

Early menarche may increase mitotic of myometrium cell during reproductive period, so it can increase the chance of gen mutation that control myometrium profileration, ${ }^{6}$ and otherwise can prolonged estrogen exposure. ${ }^{4}$ This research shows that patient who had history of menarche at 12-13 years old has bigger percentage of $15.2 \%$. But it could be caused by the lack of data in medical history.

\section{CONCLUSION}

Total uterine leiomyoma patient in Department od Obstetrics and Gynecology of Soetomo Hospital Surabaya, from January to December 2014 were majo-rity female, in the amount of 145 people who are aged forty years and older $(69.7 \%)$. Uterine leiomyoma often occur in patient within their reproductive period $(31 \%)$.

Only $2.8 \%$ patient used oral contraceptive and $15.2 \%$ had menarche at the age of 12-13 years. The number of uterine leiomyoma was higher in female who had history of pregnancy less than or equal to two times (35.2\%) followed by patient who hasn't history of pregnancy $(24.8 \%)$. Then dominated by patients who had history of birth less than or equal to two times (37.2\%) followed by nulliparity (29.7\%).

A proportion of $63.4 \%$ patient never consume cigarette. Moreover, $29.7 \%$ of patients were overweight female. Unfortu-nately, there is no data about family history, exercise habit and history of tissue injury in the medical record. With the lack of information, it still needs further studies with more complete data for better accuracy.

\section{REFERENCES}

1. Berek JS. Berek \& Novak's Gynecology, 14th Edition. Lippincott Williams \& Wilkins; 2007

2. Khan AT, Shehmar M, Gupta JK. Uterine fibroids: current perspectives. International Journal of Women's Health. 2014;6:95-114.

3. Medikare V, Kandukuri L, Ananthapur V, et al. The genetic bases of uterine fibroids; A review. Journal Reproduction and Infertility. 2011;12(3): 181-91

4. Schorge JO, et al. Williams Gynecology. China: The McGraw-Hill Companies, Inc.; 2008

5. Wise LA, Palmer JR, Stewart EA, Rosenberg L. 2005. Age-specific incidence rates for self-reported uterine leiomyomata in the Black Women's Health Study. Obstet Gynecol. 2005;105(3);563-8.

6. Flake G, Andersen J, Dixon D. 2003. Etiology and pathogenesis of uterine leiomyomas: A review. Environmental Health Perspectives. 2003;111(8): 1037-1054.

7. Takeda T. 2008. Relationship between metabolic syndrome and uterine leiomyomas: A case-control study. Gynecology and Obstetric Investigation. 2008;66:14-17.

8. Templeman C, Marshall SF, Clarke CA, et al. 2009. Risk factors for surgically-removed fibroids in a large cohort of teachers. Fertil Steril. 2009;92(4): 1436-46.

9. Zimmermann, A, Bernuit D, Gerlinger C, et al. 2012. Prevalence, symptoms and management of uterine fibroids: an international internet-based survey of 21,746 women. BMC Womens Health. 2012;12:6.

10. Sparic R, Mirkovic L, Malvasi A, Tinelli A. 2016. Epidemiology of uterine myomas: A review. International Journal of Fertility and Sterility. 2016;9(4): 424-35.

11. Parker WH. Etiology, symptomatology, and diagnosis of uterine myoma. Santa Monica: American Society for Reproductive Medicine; 2007

12. Qin J, Yang T, Kong F et al. Oral contra-ceptive use and uterine leiomyoma risk: a meta-analysis based on cohort and case-control studies. Arch Gynecol Obstet. 2013;288:139

13. Hillard PJ. Berek \& Novak's Gynecology, 14th edition. Lippincott Williams \& Wilkins; 2007.

14. Bieber EJ, Sanfilippo JS, Horowitz IR, Shafi MI. Clinical gynecology. Cambridge: Cambridge University Press; 2015. 
15. Ministry of Health, Health Research and Development Board. Laporan Hasil Riset Kesehatan Dasar. Jakarta: Badan Litbang Kesehatan, Kemenkes; 2010.

16. American College of Obstetrics and Gynaecologist. 2015. Menstrual in Girls and Adolescent: Using the
Menstrual Cycle as a Vital Sign. Committee on adolescent health care vol 651. [internet] [cited 2016 Nov 27]. Available from https://www.acog. org/-/media/Committee-Opinions/Committee-onAdolescent-Health-Care/co651.pdf?dmc=1\&ts= $20161221 \mathrm{~T} 072717574$ 